\title{
The Euro-Dollar Market: Some First Principles
}

\author{
by MILTON FRIEDMAN
}

\begin{abstract}
Increasing concern over recurring U.S. balance-of-payments deficits has prompted authorities, both here and abroad, to remexamine some aspects of the international monetary system. One of the most elusive and probably least understood aspects of this system is the Eurodollar Market.

The following article by Professor Milton Friedman of the University of Chicago is presented in the Review to provide the general reader with a basic understanding of the Eurodollar market. This article was first published in the October 1969 "Morgan Guaranty Survey". We wish to acknowledge and thank Professor Friedman and the Morgan Guaranty Trust Company for permission to reprint this article. In granting his permission to reprint this article, Professor Friedman stressed that much of the apparent controversy in discussions since his article was first published is due to the failure of subsequent writers to distinguish clearly between Eurodollar creation and the Eurodollar multiplier. This distinction is explained in the section under the heading, "Some Complications", appearing on page 20 in this ReviEw.
\end{abstract}

$\mathrm{T}$ HE Euro-dollar market is the latest example of the mystifying quality of money creation to even the most sophisticated bankers, let alone other businessmen. Recently, I heard a high official of an intemational financial organization discuss the Eurodollar market before a collection of high-powered international bankers. He estimated that Euro-dollar deposits totaled some $\$ 30$ billion. He was then asked: "What is the source of these deposits?" His answer was: partly, U.S. balance-of-payments deficits; partly, dollar reserves of non-U.S. central banks; partly, the proceeds from the sale of Euro-dollar bonds.

This answer is almost complete nonsense. Balanceof-payments deficits do provide foreigners with claims on U.S. dollars. But there is nothing to assure that such claims will be held in the form of Euro-dollars. In any event, U.S. deficits, worldwide, have totaled less than $\$ 9$ billion for the past five years, on a liquidity basis. Dollar holdings of non-U.S. central banks have fallen during the period of rapid rise in Euro-dollar deposits but by less than $\$ 5$ billion. The dollars paid for Euro-bonds had themselves to come from somewhere and do not constitute an independent source. No matter how you try, you cannot get $\$ 30$ billion from these sources. The answer given is precisely parallel to saying that the source of the $\$ 400$ billion of deposits in U.S. banks (or for that matter the much larger total of all outstanding short-term

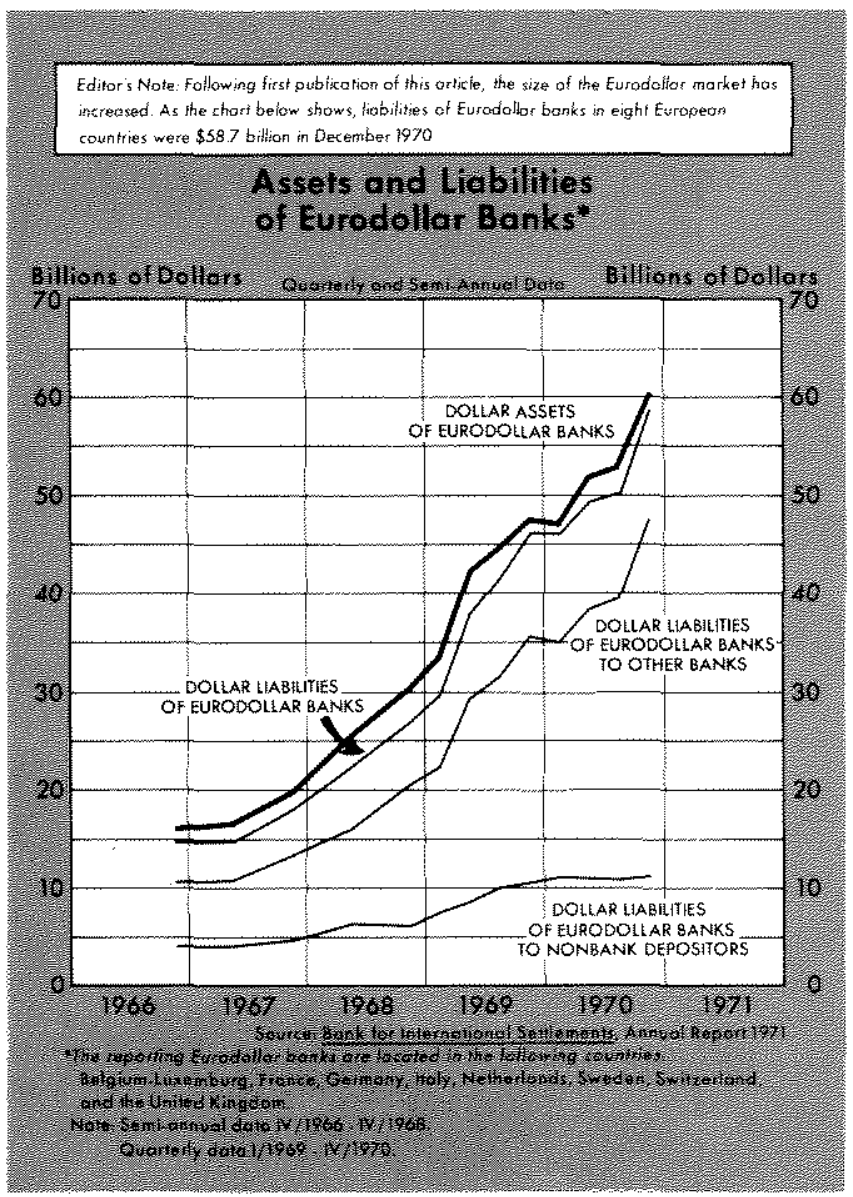


claims) is the $\$ 60$ billion of Federal Reserve credit outstanding.

The correct answer for both Euro-dollars and liabilities of U.S. banks is that their major source is a bookkeeper's pen. ${ }^{1}$ The purpose of this article is to explain this statement. The purpose is purely expository. I shall restrict myself essentially to principle and shall not attempt either an empirical evaluation of the Euro-dollar market or a normative judgment of its desirability.

Another striking example of the confusion about Euro-dollars is the discussion, in even the most sophisticated financial papers, of the use of the Euro-dollar market by U.S. commercial banks "to evade tight money," as it is generally phrased. U.S. banks, one reads in a leading financial paper, "have been willing to pay extremely high interest rates . . . to borrow back huge sums of U.S. dollars that have piled up abroad." The image conveyed is that of piles of dollar bills being bundled up and shipped across the ocean on planes and ships - the way New York literally did drain gold from Europe in the bad - or good - old days at times of financial panic. Yet, the more dollars U.S. banks "borrow back" the more Euro-dollar deposits go up! How come? The answer is that it is purely figurative language to speak of "piled up" dollars being "borrowed back." Again, the bookkeeper's pen is at work.

\section{What are Lwo-dollars?}

Just what are Euro-dollars? They are deposit liabilities, denominated in dollars, of banks outside the United States. Engaged in Euro-dollar business, for example, are foreign commercial banks such as the Bank of London and South America, Ltd, merchant banks such as Morgan Grenfell and Co., Ltd., and many of the foreign branches of U.S. commercial banks. Funds placed with these institutions may be owned by anyone - U.S, or foreign residents or citizens, individuals or corporations or governments. Eurodollars have two basic characteristics; first, they are short-term obligations to pay dollars; second, they are obligations of banking offices located outside the U.S.

\footnotetext{
The similarity between credit creation in the U.S. fractional reserve banking system and in the Euro-dollar market has of course often been noted. For example, see Fred H. Klopstock, "The Euro-Dollar Market, Some Unresolved Issues," Essays in International Finance, No. 65 (Princeton, March, 1968), p. 6. A recent excellent analysis is given in an article by Joseph G. Kvasnicka, "Euro-Dollars - an Inportant Source of Funds for American Banks," Business Conditions, Federal Reserve Bank of Chicago, June, 1969. A useful but analytically less satisfactory examination of the Euro-dollar market is Jane Sneddon Little, "The Euro-Dollar Market: Its Nature and Impact," New England Economic Review, Federal Reserve Bank of Boston, May/June, 1969.
}

In principle, there is no hard and fast line between Euro-dollars and other dollar denominated claims on non-U.S. institutions - just as there is none between claims in the U.S. that we call "money" and other short-term claims. The precise line drawn in practice depends on the exact interpretation given to "shortterm" and to "banks." Nothing essential in this article is affected by the precise point at which the line is drawn.

A homely parallel to Euro-dollars is to be found in the dollar deposit liabilities of bank offices located in the city of Chicago - which could similarly be called "Chicago dollars." Like Euro-dollars, "Chicago dollars" consist of obligations to pay dollars by a collection of banking offices located in a particular geographic area. Again, like Euro-dollars, they may be owned by anyone - residents or nonresidents of the geographic area in question.

The location of the banks is important primarily because it affects the regulations under which the banks operate and hence the way that they can do business. Those Chicago banks that are members of the Federal Reserve System must comply with the System's requirements about reserves, maximum interest rates payable on deposits, and so on; and in addition, of course, with the requirements of the Comptroller of the Currency if they are national banks, and of the Illinois State Banking Commission if they are state banks.

Euro-dollar banks are subject to the regulations of the relevant banking authorities in the country in which they operate. In practice, however, such banks have been subject neither to required reserves on Euro-dollar deposits nor to maximum ceilings on the rates of interest they are permitted to pay on such deposits.

\section{Regulation and Eurodollars}

The difference in regulation has played a key role in the development of the Euro-dollar market. No doubt there were minor precursors, but the initial substantial Euro-dollar deposits in the post-World War II period originated with the Russians, who wanted dollar balances but recalled that their dollar holdings in the U.S. had been impounded by the Alien Property Custodian in Wrold War II. Hence they wanted dollar claims not subject to U.S governmental control.

The most important regulation that has stimulated the development of the Euro-dollar market has been Regulation Q, under which the Federal Reserve has 
fixed maximum interest rates that member banks could pay on time deposits. Whenever these ceilings became effective, Euro-dollar deposits, paying a higher interest rate, became more attractive than U.S. deposits, and the Euro-dollar market expanded. U.S. banks then borrowed from the Euro-dollar market to replace the withdrawn time deposits.

A third major foree has been the direet and indirect exchange controls imposed by the U.S. for "balanceof-payments" purposes - the interestequalization tax, the "voluntary" controls on bank lending abroad and on foreign investment, and, finally, the compulsory controls instituted by President Johnson in January 1968. Without Regulation $Q$ and the exchange controls - all of which, in my opinion, are both unnecessary and undesirable - the Euro-dollar market, though it might still have existed, would not have reached anything like its present dimensions.

\section{Fractional reserves}

Euro-dollar deposits like "Chicago deposits" are in principle obligations to pay literal dollars - i.e., currency (or coin), all of which consists, at present, of government-issued fiat (Federal Reserve notes, U.S. notes, a few other similar issues, and fractional coinage). In practice, even Chicago banks are called on to discharge only an insignificant part of their deposit obligations by paying out currency. Eurodollar banks are called on to discharge a negligible part in this form. Deposit obligations are typically discharged by providing a credit or deposit at another bank - as when you draw a check on your bank which the recipient "deposits" in his.

To meet their obligations to pay cash, banks keep a "reserve" of cash on hand. But, of course, since they are continuously receiving as well as paying cash and since in any interval they will be called on to redeem only a small fraction of their obligations in cash, they need on the average keep only a very small part of their assets in cash for this purpose. For Chicago banks, this cash serves also to meet legal reserve requirements. For Euro-dollar banks, the amount of literal cash they hold is negligible.

To meet their obligations to provide a credit at another bank, when a check or similar instrument is used, banks keep deposits at other banks. For Chicago banks, these deposits (which in addition to facilitating the transfer of funds between banks serve to meet legal reserve requirements) are held primarily at Federal Reserve banks. In addition, however, Chicago banks may also keep balances at correspondent banks in other cities.
Like cash, deposits at other banks need be only a small fraction of assets. Banks are continuously receiving funds from other banks, as well as transferring funds to them, so they need reserves only to provide for temporary discrepancies between payments and receipts or sudden unanticipated demands. For Chicago banks, such "prudential" reserves are clearly far smaller than the reserves that they are legally required to keep.

Euro-dollar banks are not subject to legal reserve requirements, but, like Chicago banks, they must keep a prudential reserve in order to be prepared to meet withdrawals of deposits when they are demanded or when they mature. An individual bank will regard as a prudential reserve readily realizable funds both in the Euro-dollar market itself (e.g., Euro-dollar call money) and in the U.S. But for the Euro-dollar system as a whole, Euro-dollar funds cancel, and the prudential reserves available to meet demands for U.S. dollars consist entirely of deposits at banks in New York or other cities in the U.S. and U.S. money market assets that can be liquidated promptly without loss.

The amount of prudential reserves that a Eurodollar bank will wish to hold - like the amount that a Chicago bank will wish to hold - will depend on its particular mix of demand and time obligations. Time deposits generally require smaller reserves than demand deposits - and in some instances almost zero reserves if the bank can match closely the maturities of its dollar-denominated liabilities and its dollardenominated loans and investments. Although a precise estimate is difficult to make because of the incompleteness and ambiguity of the available data, prudential reserves of Euro-dollar institutions are clearly a small fraction of total dollar-denominated obligations.

This point - that Euro-dollar institutions, like Chicago banks, are part of a fractional reserve banking system - is the key to understanding the Euro-dollar market. The failure to recognize it is the chief source of misunderstanding about the Euro-dollar market. Most journalistic discussions of the Euro-dollar market proceed as if a Euro-dollar bank held a dollar in the form of cash or of deposits at a U.S. bank corresponding to each dollar of deposit liability. That is the source of such images as "piling up," "borrowing back," "withdrawing," etc. But of course this is not the case. If it were, a Euro-dollar bank could hardly afford to pay $10 \%$ or more on its deposit liabilities. 


\section{A hypothetical example}

A Euro-dollar bank typically has total dollar assets roughly equal to its dollar liabilities. ${ }^{2}$ But these assets are not in currency or bank deposits. In highly simplified form, the balance sheet of such a bank - or the part of the balance sheet corresponding to its Euro-dollar operations - must look something like that shown below (the numbers in this and later balance sheets are solely for illustrative purposes).

It is the earnings on the $\$ 9,500,000$ of loans and investments that enable it to pay interest on the $\$ 10,000,000$ of deposits.

Where did the $\$ 10,000,000$ of deposits come from? One can say that $\$ 700,000$ (cash assets minus due to other banks) came from "primary deposits," i.e., is the counterpart to a literal deposit of cash or transfer of funds from other banks." The other $\$ 9,300,000$ is "created" by the magic of fractional reserve banking - this is the bookkeeper's pen at work.

Let us look at the process more closely. Suppose an Arab Sheik upens up a new deposit account in London at Bank $\mathrm{H}$ ( $\boldsymbol{H}$ for hypothetical) by depositing a check for $\$ 1,000,000$ drawn on the Sheik's demand deposit account at the head office of, say, Morgan Guaranty Trust Company. Let us suppose that Bank $H$ also keeps its N.Y. account at Morgan Guaranty and also as demand deposits. At the first stage, this will add $\$ 1,000,000$ to the deposit liabilities of Bank $H$, and the same amount to its assets in the form of deposits due from New York banks. At Morgan Guaranty, the transfer of deposits from the Sheik to Bank $\mathrm{H}$ will cause no change in total deposit liabilities.

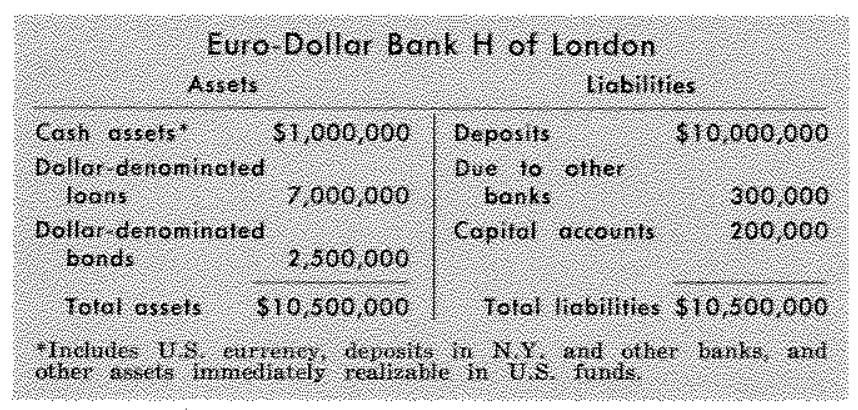

2Which is why it is not subject to any special foreign exchange risk simply by operating in the Euro-dollar market. The balance sheet of its Emro-dollar operations balances in dollars; if it is, for example, a British bank, the balance sheet of its pound sterling operations balances in pounds. It is operating in two currencies but need not take a speculative position in either. Of course, it may take a speculative position, whether or not it operates in the Euro-dollar market.

Note that even this is an overstatement, since most of the deposits at N.Y. banks are thenselves ultimately "created" rather than "primary" deposits. These are primary deposits only vis-àmvis the Euro-dollar market separately.
But Bank $\mathrm{H}$ now has excess funds available to lend. It has been keeping cash assets equal to $10 \%$ of deposits - not because it was required to do so but because it deemed it prudent to do so. It now has cash equal to $18 \%(2 / 11)$ of deposits. Because of the $\$ 1,000,000$ of new deposits from the Sheik, it will want to add, say, $\$ 100,000$ to its balance in New York. This leaves Bank $H$ with $\$ 900,000$ available to add to its loans and investments. Assume that it makes a loan of $\$ 900,000$ to, say, UK Ltd., a British corporation engaged in trade with the U.S., giving corporation UK Ltd. a check on Morgan Guaranty. Bank $H^{\prime}$ 's balance sheet will now look as follows after the check has cleared:

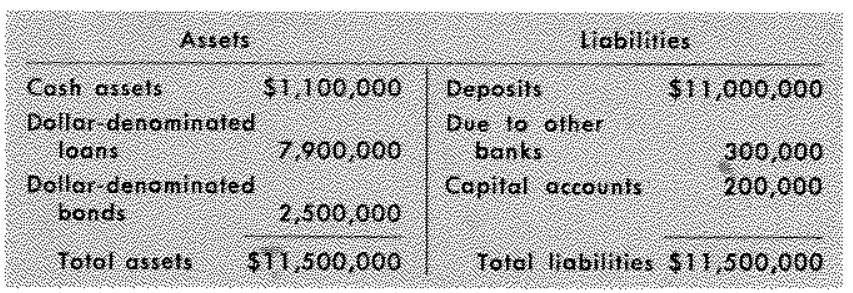

We now must ask what UK Ltd. does with the $\$ 900,000$ check. To cut short and simplify the process, let us assume that UK Ltd. incurred the loan because it had been repeatedly troubled by a shortage of funds in New York and wanted to maintain a higher average level of bank balances in New York. Further assume that it also keeps its account at Morgan Guaranty, so that it simply deposits the check in its demand deposit account.

This particular cycle is therefore terminated and we can examine its effect. First, the position of Morgan Guaranty is fundamentally unchanged: it had a deposit liability of $\$ 1,000,000$ to the Sheik. It now has a deposit liability of $\$ 100,000$ to Bank $\mathrm{H}$ and one of $\$ 900,000$ to UK Ltd.

Second, the calculated money supply of the U.S. and the demand deposit component thereof are unchanged. That money supply excludes from "adjusted demand deposits" the deposits of U.S. commercial banks at other U.S. commercial banks but it includes deposits of both foreign banks and other foreigners. Therefore, the Sheik's deposit was included before. The deposits of Bank $H$ and UK Ltd. are included now.

Third, the example was set up so that the money supply owned by residents of the U.S. is also unchanged. As a practical matter, the financial statistics gathered and published by the Federal Reserve do not contain sufficient data to permit calculation of the U.S.-owned money supply - a total which would exclude from the money supply as now calculated cur- 
rency and deposits at U.S. banks owned by nonresidents and include dollar deposits at non-U.S. banks owned by residents. But the hypothetical transactions clearly leave this total unaffected.

Fourth, Euro-dollar deposits are $\$ 1,000,000$ higher.

However, fifth, the total world supply of dollars held by nonbanks - dollars in the U.S. plus dollars outside the U.S. - is $\$ 900,000$ not $\$ 1,000,000$ higher. The reason is that interbank deposits are now higher by $\$ 100,000$, thanks to the additional deposits of Bank $\mathrm{H}$ at Morgan Guaranty. This amount of deposits was formerly an asset of a nonbank (the Arab Sheik); now it is an asset of Bank $H$. In this way, Bank $H$ has created $\$ 900,000$ of Euro-dollar deposits. The other $\$ 100,000$ of Euro-dollar deposits has been trans. ferred from the U.S. to the Euro-dollar area.

Sixth, the balance of payments of the U.S. is unaffected, whether calculated on a liquidity basis or on an official settlements basis. On a liquidity basis, the Arab Sheik's transfer is recorded as a reduction of $\$ 1,000,000$ in short-term liquid claims on the U.S. but the increased deposits of Bank $\mathrm{H}$ and UK Ltd. at Morgan Guaranty are a precisely offsetting increase. On an official settlements basis, the series of trans. actions has not affected the dollar holdings of any central bank or official institution. ${ }^{*}$

${ }^{4}$ It is interesting to contrast these effects with those that would have occurred if we substitute a Chicago bink for Bank $\mathbf{H}$ of London, i.e., suppose that the Arab Sheik had transferred his funds to a (hicago bank, say, Continental Illinois, and Continental lllinois had made the loan to UK Ltd, which UK Ltd. again added to its balances at Morgan Guaranty. To simplify matters, assume that the reserve requirements for Continental Illinois and Morgan Guaranty are the same flat $10 \%$ that we assumed Bank $H$ of London kept in the form of cash assets (because, let us say, all deposit changes consist of the appropriate mix of demand and time deposits).

First the position of Morgan Guaranty is now fundamentally changed. Continental Illinois keeps its reserves as deposits at the Federal Reserve Bank of Chicago, not at Morgan Guaranty. Hence it will deposit its net claim of $\$ 100,000$ on Morgan Guaranty at the Chicago Fed to meet the reserves required for the Sheik's deposit. This will result in a reduction of $\$ 100,000$ in Morgan Guaranty's teserve balance at the New York Fed. Its deposits have gone down only $\$ 100,000$ (thanks to the $\$ 900,000$ deposit by UK Ltd.) so that if it had no excess reserves before it now has deficient reserves. This will set in train a multiple contraction of deposits at Morgan Guaranty and other banks which will end when the $\$ 1,000,000$ gain in deposits by Continental Illinois is completely offset by a $\$ 1,000,000$ decline in deposits at Morgan Guaranty and other barks.

Second, the calculated money supply of the U.S and the demand deposit component thereof are still unchanged.

However, third, the money supply owned by the residents of the U.S. is reduced by the $\$ 900,000$ increase in the deposits of UK Ltd.

Fourth, there is no change in Euro-dollar deposits.

Fifth, there is no change in the total world supply of dollars.

Sixth the balance of payments of the U.S. is affected if it is calculated on a licquidity basis but not if it is calculated on an official settlements basis. On a liquidity basis, the
Clearly, there is no meaningful sense in which we can say that the $\$ 900,000$ of created Euro-dollar deposits is derived from a U.S. balance-of-payments deficit, or from dollars held by central banks, or from the proceeds of Euro-dollar bond sales.

\section{Some complications}

Many complications of this example are possible. They will change the numbers but not in any way the essential principles. But it may help to consider one or two.

(a) Suppose UK Ltd. used the dollar loan to pur. chase timber from Russia, and Russia wished to hold the proceeds as a dollar deposit at, say, Bank $\mathrm{R}$ in London. Then, another round is started-precisely like the one that began when the Sheik transferred funds from Morgan Guaranty to Bank H. Bank R now has $\$ 900,000$ extra deposit liabilities, matched by $\$ 900,000$ extra deposits in New York. If it also follows the practice of maintaining cash assets equal to $10 \%$ of deposits, it can make a dollar loan of $\$ 810,000$. If the recipient of the loan keeps it as a demand deposit at Morgan Guaranty, or transfers it to someone who does, the process comes to an end. The result is that total Euro-dollar deposits are up by $\$ 1,900,000$. Of that total, $\$ 1,710,000$ is held by nonbanks, with the other $\$ 190,000$ being additional deposits of banks (the $\$ 100,000$ extra of Bank $\mathbf{H}$ at Morgan Guaranty plus the $\$ 90,000$ extra of Bank $R$ at Morgan Guaranty).

If the recipient of the loan transfers it to someone who wants to hold it as a Euro-dollar deposit at a third bank, the process continues on its merry way. If, in the extreme, at every stage, the whole of the proceeds of the loan were to end up as Euro-dollar deposits, it is obvious that the total increase in Eurodollar deposits would be: $1,000,000+900,000+810,000$ $+729,000+\ldots \ldots \ldots=10,000,000$. At the end of the process, Euro-dollar deposits would be $\$ 10,000,000$ higher; deposits of Euro-dollar banks at N. Y. banks, $\$ 1,000,000$ higher; and the total world supply of dol lars held by nonbanks, $\$ 9,000,000$ higher.

deficit would be increased by $\$ 900,000$ because the loan by Continental Illinois to UK Ltd. would be recorded as a capital outflow but UK Ltd,'s deposit at Morgan Guaranty would be regarded as an inerease in U.S. liquid liabilities to foreigners, which are treated as financing the deficit. This enlargement of the deficit on a liguidity basis is highly misleading. It suggests, of course, a worsening of the U.S. payments problem, whereas in fact all that is involved is a worsening of the statistics. The additional dollars that UK Ltd. has in its demand deposit account cannot meaningfully be regarded as a potential claim on U.S. reserve assets. UK Ltd. not only needs them for transactions purposes; it must regard them as fied or matched to its own dollar indebtedness. On an official settlements hasis, the series of transactions does not affect the dollar holdings of any central bank or official instatution. 
This example perhaps makes it clear why bankers in the Euro-dollar market keep insisting that they do not "create" dollars but only transfer them, and why they sincerely believe that all Euro-dollars come from the U.S. To each banker separately in the chain described, his additional Euro-dollar deposit came in the form of a check on Morgan Guaranty Trust Company of New York! How are the bankers to know that the $\$ 10,000,000$ of checks on Morgan Guaranty all constitute repeated claims on the same initial $\$ 1,000,000$ of deposits? Appearances are deceiving.

This example (involving successive loan extensions by a series of banks) brings out the difference between two concepts that have produced much confusion: Euro-dollar creation and the Euro-dollar multiplier. In both the simple example and the example involving successive loan extensions, the fraction of Euro-dollars outstanding that has been created is nine-tenths, or, put differently, 10 Euro-dollars exist for every U.S. dollar held as a cash asset in New York by Euro-dollar banks. However, in the simple example, the Euro-dollar multiplier (the ratio of the increase in Euro-dollar deposits to the initial "primary" desposit) is unity; in the second example, it is 10 . That is, in the simple example, the total amount of Euro-dollars goes up by $\$ 1$ for every $\$ 1$ of U.S. deposits initially transferred to Euro-dollar banks; in the second example, it goes up by $\$ 10$ for every $\$ 1$ of U.S. deposits initially transferred. The difference is that in the simple example there is maximum "leakage" from the Euro-dollar system; in the second example, zero "leakage."

The distinction between Euro-dollar creation and the Euro-dollar multiplier makes it clear why there is a definite limit to the amount of Euro-dollars that can be created no matter how low are the prudential reserves that banks hold. For example, if Euro-dollar banks held zero prudential reserves - as it is sometimes claimed that they do against time deposits $100 \%$ of the outstanding deposits would be created deposits and the potential multiplier would be infinite. Yet the actual multiplier would be close to unity because only a small part of the funds acquired by borrowers from Euro-dollar banks would end up as additional time deposits in such banks. ${ }^{5}$

(b) Suppose Bank H does not have sufficient demand for dollar loans to use profitably the whole $\$ 900,000$ of excess dollar funds. Suppose, simultaneously, it is experiencing a heavy demand for sterling loans. It might go to the Bank of England and use

\footnotetext{
5 This is precisely comparable to the situation of savings and
} loan associations and mutual savings banks in the U.S. the $\$ 900,000$ to buy sterling. Bank of England deposits at Morgan Guaranty would now go up. But since the Bank of England typically holds its deposits at the New York Federal Reserve Bank, the funds would fairly quickly disappear from Morgan Guaranty's books and show up instead on the Fed's. This, in the first instance, would reduce the reserves of Morgan Guaranty and thus threaten to produce much more extensive monetary effects than any of our other examples. However, the Bank of England typically holds most of its dollar reserves as Treasury bills or the equivalent, not as noninterest earning deposits at the Fed. It would therefore instruct the Fed to buy, say, bills for its account. This would restore the reserves to the banking system and, except for details, we would be back to where we were in the other examples.

\section{The key points}

Needless to say, this is far from a comprehensive survey of all the possible complications. But perhaps it suffices to show that the complications do not affect the fundamental points brought out by the simple example, namely:

1. Euro-dollars, like "Chicago dollars," are mostly the product of the bookkeeper's pen - that is, the result of fractional reserve banking.

2. The amount of Euro-dollars outstanding, like the amount of "Chicago dollars," depends on the desire of owners of wealth to hold the liabilities of the corresponding group of banks.

3. The ultimate increase in the amount of Eurodollars from an initial transfer of deposits from other banks to Euro-dollar banks depends on:

(a) The amount of their dollar assets Euro-dollar banks choose to hold in the form of cash assets in the U.S., and

(b) The "leakages" from the system-i.e, the final disposition of the funds borrowed from Eurodollar banks (or acquired by the sale of bonds or other investments to them). The larger the fraction of such funds held as Euro-dollar deposits, the larger the increase in Euro-dollars in total.

4. The existence of the Euro-dollar market increases the total amount of dollar balances available to be held by nonbanks throughout the world for any given amount of money (currency plus deposits at Federal Reserve Banks) created by the Federal Reserve System. It does so by permitting a greater pyramiding on this base by the use of deposits at U.S. banks as prudential reserves for Euro-dollar deposits. 
5. The existence of the Euro-dollar market may also create a greater demand for dollars to be held by making dollar balances available in a more convenient form. The net effect of the Euro-dollar market on our balance-of-payments problem (as distinct from our statistical position) depends on whether demand is raised more or less than supply.

My own conjecture - which is based on much too little evidence for me to have much confidence in it is that demand is raised less than supply and hence that the growth of the Euro-dollar market has on the whole made our balance-of-payments problem more difficult.

6. Whether my conjecture on this score is right or wrong, the Euro-dollar market has almost surely raised the world's nominal money supply (expressed in dollar equivalents) and has thus made the world price level (expressed in dollar equivalents) higher than it would otherwise be. Atternatively, if it is desired to define the money supply exclusive of Euro-dollar deposits, the same effect can be described in terms of a rise in the velocity of the world's money supply. However, this effect, while clear in direction, must be extremely small in magnitude.

\section{Use of Euro-dollars by U.S.banks}

Let us now turn from this general question of the source of Euro-dollars to the special issue raised at the outset: the effect of Regulation $Q$ and "tight money" on the use of the Euro-dollar market by U.S. banks.

To set the stage, let us suppose, in the framework of our simple example, that Euro-dollar Bank $\mathrm{H}$ of London loans the $\$ 900,000$ excess funds that it has as a result of the initial deposit by the Arab Sheik to the head office of Morgan Guaranty, i.e, gives Morgan Guaranty (New York) a check for $\$ 900,000$ on itself in return for an 1.O.U. from Morgan Guaranty. This kind of borrowing from foreign banks is one of the means by which American banks have blunted the impact of CD losses. The combined effect will be to leave total liabilities of Morgan Guaranty unchanged but to alter their composition: deposit liabilities are now down $\$ 900,000$ (instead of the $\$ 1,000,000$ deposit liability it formerly had to the Sheik it now has a deposit liability of $\$ 100,000$ to Bank H) and other liabilities ("funds borrowed from foreign banks") are up $\$ 900,000$.

Until very recently, such a change in the form of a bank's liabilities - from deposits to borrowings had an important effect on its reserve position. Spe- cifically, it freed reserves. With $\$ 1,000,000$ of demand deposit liabilities to the Arab Sheik, Morgan Guaranty was required to keep in cash or as deposits at the Federal Reserve Bank of New York $\$ 175,000$ (or $\$ 60,000$ if, as is more realistic, the Sheik kept his $\$ 1,000,000$ in the form of a time deposit). With the shift of the funds to Bank $H$, however, and completion of the $\$ 900,000$ loan by Bank $\mathrm{H}$ to Morgan Guaranty, Morgan Guaranty's reserve requirements at the Fed fell appreciably. Before the issuance of new regulations that became effective on September 4 of this year, Morgan Guaranty was not required to keep any reserve for the liability in the form of the I.O.U. Its only obligation was to keep $\$ 17,500$ corresponding to the demand deposit of Bank $H$. The change in the form of its liabilities would therefore have reduced its reserve requirements by $\$ 157,500$ (or by $\$ 42,500$ for a time deposit) without any change in its total liabilities or its total assets, or in the composition of its assets; hence it would have had this much more available to lend.

What the Fed did effective September 4 was to make borrowings subject to reserve requirements as well. Morgan Guaranty must now keep a reserve against the I.O.U., the exact percentage depending on the total amount of borrowings by Morgan Guaranty from foreign banks. "The new regulations make it impossible to generalize about reserve effects. A U.S. bank losing deposits to a Euro-bank and then recouping funds by giving its I.O.U. may or may not have additional amounts available to lend as a result of transactions of the kind described.

If Bank $\mathrm{H}$ made the loan to Chase instead of to Morgan Guaranty, the latter would lose reserves and Chase would gain them. To Chase, it would look as if it were getting additional funds from abroad, but to both together, the effect would be the same as before - the possible release of required reserves with no change in available reserves.

The bookkeeping character of these transactions, and how they can be stimulated, can perhaps be scen more clearly if we introduce an additional feeture of the actual Euro-dollar market, which was not essential heretofore, namely, the role of overseas branches of U.S. banks. In addition, for realism, we shall express our example in terms of time deposits.

Let is start from scratch and consider the head office of Morgan Guaranty in New York and its Lon-

\footnotetext{
The required reserve is $3 \%$ of such borrowings so long as they do not exceed $4 \%$ of total deposits subject to reserves. On borrowings in excess of that level the required reserve is $10 \%$.
} 
don branch. Let us look at hypothetical initial balance sheets of both. We shall treat the London branch as if it had just started and had neither assets nor liabilities, and shall restrict the balance sheet for the head office to the part relevant to its CD operations. This set of circumstances gives us the following situation:

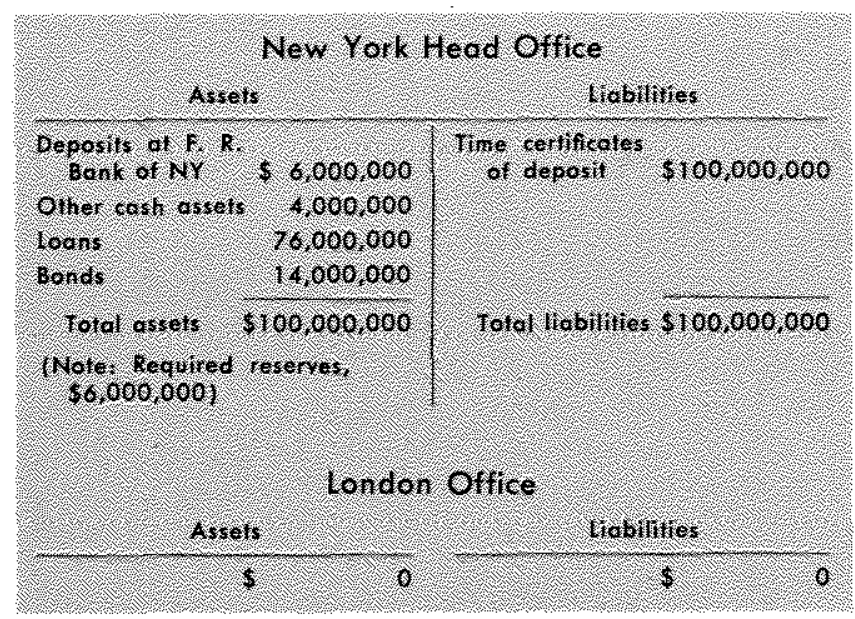

Now suppose a foreign corporation (perhaps the Arab Sheik's oil company) which holds a long-term maturing $C D$ of $\$ 10,000,000$ at Morgan Guaranty refuses to renew it because the $6 \%$ interest it is receiving seems too low. Morgan Guaranty agrees that the return should be greater, but explains it is prohibited by law from paying more. It notes, however, that its London branch is not. Accordingly, the corporation acquires a time deposit at the London office for $\$ 10,000,000$ "by depositing" the check for $\$ 10,000,000$ on the New York office it receives in return for the maturing $\mathrm{CD}$ - or, more realistically, by transfers on the books in New York and London. Let us look at the balance sheets:

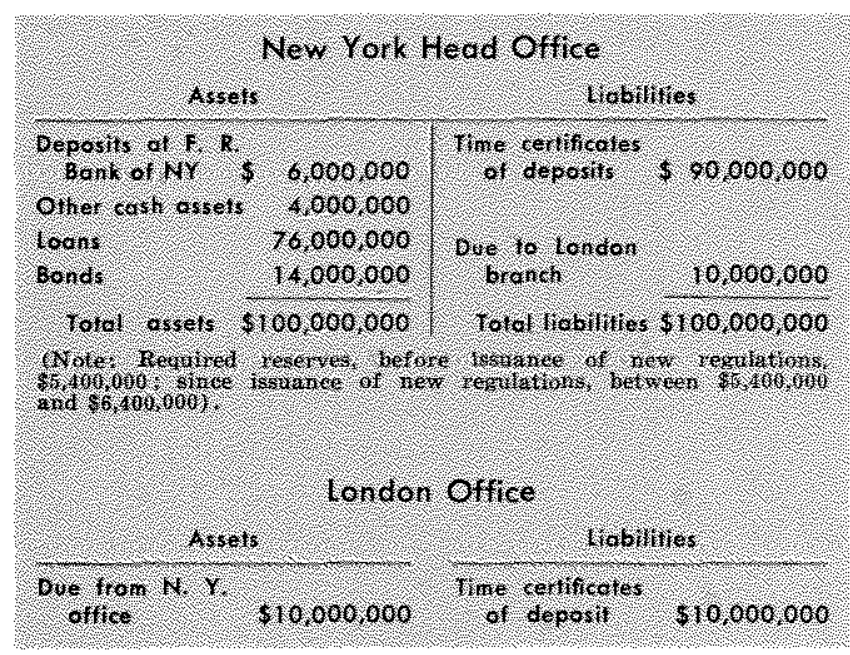

Clearly, if we consolidate the branch and the head office, the books are completely unchanged. Yet these bookkeeping transactions: (1) enabled Morgan Guaranty to pay a rate in London higher than $6^{1 \%} \%$ on some certificates of deposit; and (2) reduced its required reserves by $\$ 600,000$ prior to the recent modification of Regulation M. The reduction in required reserves arose because until recently U.S. banks were not required to keep a reserve against liabilities to their foreign branches. With the amendment of Regulation $M$, any further reduction of reserves by this route has been eliminated since the Fed now requires a reserve of $10 \%$ on the amount due to branch offices in excess of the amount due on average during May. ${ }^{7}$

\section{Hypocrisy and window dressing}

This example has been expressed in terms of a foreign corporation because the story is a bit more complicated for a U.S. corporation, though the end result is the same. First, a U.S. corporation that transfers its funds from a certificate of deposit at a U.S. bank to a deposit at a bank abroad - whether a foreign bank or an overseas branch of a U.S. bank - is deemed by the Department of Commerce to have made a foreign investment. It may do so only if it is within its quota under the direct control over foreign investment with which we are still unfortunately saddled. Second, under pressure from the Fed, commercial banks will not facilitate direct transfers by U.S. corporations - indeed, many will not accept time deposits from U.S. corporations at their overseas branches, whether their own customers or not, unless the corporation can demonstrate that the deposit is being made for an "international" purpose. However, precisely the same results can be accomplished by a U.S. holder of a CD making a deposit in a foreign bank and the foreign bank in turn making a deposit in, or a loan to, the overseas branch of a U.S. bank. As always, this kind of moral suasion does not prevent profitable transactions. It simply produces hypocrisy and window dressing-in this case, by unnecessarily giving business to competitors of U.S. banks!

The final effect is precisely the same as in the simple example of the foreign corporation. That ex-

\footnotetext{
${ }^{7}$ An amendment to Regulation M effective September 4 established a $10 \%$ reserve requirement on head office liabilities to overseas branches on that portion of such liabilities in excess of the average amount on the books in the four-week period ending May 28, 1969.
} 
ample shows, in highly simplifed form, the main way U.S. banks have used the Euro-dollar market and explains why it is that the more they "borrow" or "bring back" from the Euro-dollar market, the higher Euro-dollar deposits mount. In our example, borrowing went up $\$ 10,000,000$ and so did deposits.

From January 1, 1969 to July $31,1969 \mathrm{CD}$ deposit liabilities of U.S. banks went down $\$ 9.3$ billion, and U.S. banks" indebtedness to their own overseas branches went up $\$ 8.6$ billion. The closeness of these two numbers is not coincidental.

These bookkeeping operations have affected the statistics far more than the realities. The run-off in CD's in the U.S., and the accompanying decline in total commercial bank deposits (which the Fed uses as its "bank credit proxy") have been interpreted as signs of extreme monetary tightness. Money has been tight, but these figures greatly overstate the degree of tightness. The holders of CD's on U.S. banks who replaced them by Euro-dollar deposits did not have their liquidity squeezed. The banks that substituted "due to branches" for "due to depositors on time certificates of deposit" did not have their lending power reduced. The Fed's insistence on keeping Regulation $Q$ ceilings at levels below market rates has simply imposed enormous structural adjustments and shifts of funds on the commercial banking system for no social gain whatsoever.

\section{Conecting a misunderstanding}

A column that appeared in a leading financial paper just prior to the Fed's revision of reserve requirements encapsules the widespread misunderstanding about the Euro-dollar market. The Euro-dollar market, the column noted, has:

". . . ballooned as U.S. banks have discovered that they can ease the squeeze placed on them by the Federal Reserve Board by borrowing back these foreign-deposited dollars that were pumped out largely through U.S. balance-of-payments deficits. Of this pool of $\$ 30$ billion, U.S. banks as of last week had soaked up $\$ 13$ billion ...

"Thanks to this system, it takes only seconds to transmit money - and money troubles - between the U.S, and Europe . . The Federal Reserve's pending proposal to make Euro-dollar borrowing more costly to U.S. banks might make their future demands a shade less voracious, but this doesn't reduce concern about whether there will be strains in repaying the massive amounts already borrowed."

Strains there may be, but they will reflect features of the Euro-dollar market other than those stressed by this newspaper comment. The use of the Eurodollar market by commercial banks of offset the decline in CD's was primarily a bookkeeping operation. The reverse process - a rise in CD's and a matching decline in Euro-dollar borrowings - will also require little more than a bookkeeping operation.

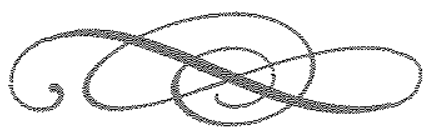

